\title{
MEASURED RE-ADVANCE OF A DEBRIS-COVERED GLACIER TERMINUS IN THE PRESIDENT RANGE, YOHO NATIONAL PARK, BRITISH COLUMBIA, CANADA
}

\author{
By R. J. Rogerson \\ (Departments of Earth Sciences and Geography, Memorial University of Newfoundland, St John's, Newfoundland A1B 3X5, \\ Canada)
}

Abstract. Measurements made at the terminus of Emerald Glacier in the Rocky Mountains of Canada indicate terminal re-advance in the order of one to two metres per year sustained since 1978 at least. Re-advance is maximum along that part of the terminus which is heavily covered with supraglacial debris, where ice remains in contact with a push-moraine all summer. Re-advance may represent fluctuations of a small, responsive ice mass, or the early effects of recent climatic deterioration.

RÉsumé. Mesure de la reprise de l'avancée d'un front de glacier recouvert de débris, Range du Président, Parc National de Yoho, Colombie Britannique, Canada. Des mesures effectuées sur le front du glacier Emerald dans les Montagnes Rocheuses du Canada indiquent une reprise d'avancée de l'ordre de un à deux mètres par an, continue depuis 1978 au moins. La reprise d'avancée est maximum le long de cette partie du front qui est fortement recouverte de débris morainiques et où la glace reste en contact avec une moraine de

\section{INTRODUCTION}

Glacier recession has been an accepted condition for high mountain areas of western Canada for the major part of the twentieth century (Heusser, 1956; Porter and Denton, 1967; Henoch, 1971; Gardner, [C1972])
Yet in recent years, there have been some indications that an increasing number of mountain glaciers may now be re-advancing.

Several large glacier termini in western Canada re-advanced in the mid to late 1960s (Athabasca Glacier, 1965-67; Saskatchewan Glacier, 1967-69; Bugaboo Glacier, 1964-75; Sphinx Glacier, 1966-68) according to photogrammetric surveys reported in Ommanney (unpublished). Of these glaciers, only Bugaboo Glacier appears to have sustained re-advance into the current decade.

More recent re-advance has been described in a number of Coast Mountain glaciers (Ricker, 1979, 1980, 1981; Tupper and Ricker, 1982). In the Clendenning and Elaho Ranges, Ricker (1980) estimates that $67 \%$ of the glaciers are in a state of re-advance; Havoc Glacier having advanced an average of $38.5 \mathrm{~m} \mathrm{a}^{-1}$ between 1970 and 1979 (Ricker, 1981). Not only are tbese readvances dramatic in amount, but they appear to be symptomatic of considerable instability in the general condition of Coast Mountain glaciers. A single year's re-advance of 5 to $8 \mathrm{~m}$ at the central point of the terminus of Wedgemount Glacier, for instance, was accompanied by substantial thinning and recession along the margin such that the terminus as a whole lost mass (Tupper and Ricker, 1982).

This paper describes re-advance at the debriscovered terminus of Emerald Glacier, Yoho National Park, which has been sustained since 1978 at least. All the larger glaciers in the Rocky Mountains are known to be receding after the brief rally of Athabasca and Saskatchewan Glaciers between 1965 and 1969.

\section{EMERALD GLACIER}

Emerald Glacier is a small, mountain shelf glacier, whose longest dimension lies normal to the direction of ice motion. The northern section of the glacier is almost separated from the rest and embraces an area of only $0.6 \mathrm{~km}^{2}$. The terminus is approximately $2200 \mathrm{~m}$ poussée pendant tout l'été. La reprise d'avancée peut être due à une légère réponse de la masse de glace ou bien aux premiers effets d'une détérioration climatique récente.

Zusammenfassung. Messung des Wiedervorstosses einer schuttbedeckten Gletscherzunge in der President Range, Yoho National Park, B.C., Kanada. Messungen an der Zunge des Emerald Glacier in den Rocky Mountains von Kanada zeigen einen Wiedervorstoss in der Grössenordnung von ein bis zwei Meter pro Jahr, der zuminest seit 1978 anhält. Sein Maximum liegt in jenem Teil der Zunge, der dicht mit oberflächlichem Schutt bedeckt ist und wo das Eis während des ganzen Sommers in Kontakt mit einer Stauchmoräne bleibt. Der Wiedervorstoss kann Schwankungen einer kleinen, empfindlichen Eismasse oder die frühe Auswirkung einer rezenten Klimaverschlechterung vorstellen.

above sea-level while the snow line at the end of the melt season was around $2500 \mathrm{~m}$ between 1978 and 1982 .

Part of the terminus has a continuous cover of supraglacial debris, while part is relatively debrisfree. Along the ice margin in both cases the glacier - is currently forming a push moraine (Rogerson and Batterson, 1982), termed moraine A along the section which is debris-covered and moraine $B$ where the proximal ice surface is debris-free. A lake called Terminal Lake lies near the eastern limit of moraine A. The moraine is between 1.5 and $4 \mathrm{~m}$ in height and consists of a single ridge for most of its length with small multiple ridges, seldom more than $1 \mathrm{~m}$ in height and breadth, characteristic of the proximal side of moraine $B$. The moraine is stratigraphically complex: Moraine A is composed of coarse supraglacial tills with injected fines from the subglacial sources, while moraine B is composed of "bulldozed" subglacial melt-out tills (Rogerson and Batterson, 1982).

\section{RE-ADVANCE OBSERVATIONS}

Where a glacier is bounded by an active terminal moraine, re-advance of the ice margin may be represented by forward displacement of markers on the moraine. This avoids the problem of locating and measuring an ice margin which in the melt-season may be in a temporary state of rapid recession due to high melt rates. In this paper, all measurements are made to moraine markers.

Between 1978 and 1980 , the record of terminal fluctuations consists of measurements and photographs of a single site where a large block was observed, lodged in the distal slope of moraine A (Site 7; Fig. 1). In July 1980 , the terminus was measured at 28 locations from 16 fixed markers on bedrock or securely lodged boulders (Fig. 2), using a steel tape. The tape was read to the nearest centimetre where possible. These measurements were repeated in September 1981 and September 1982: on these occasions several sites were measured to the nearest decimetre when more precise reading was not possible due to loss of exact site on the moraine. 


\section{EMERALD GLACIER}

SITE 7 RE-ADVANCE

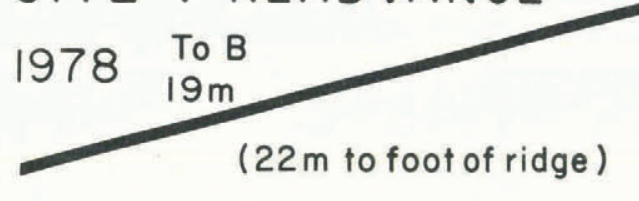

$197915.5 \mathrm{~m}$

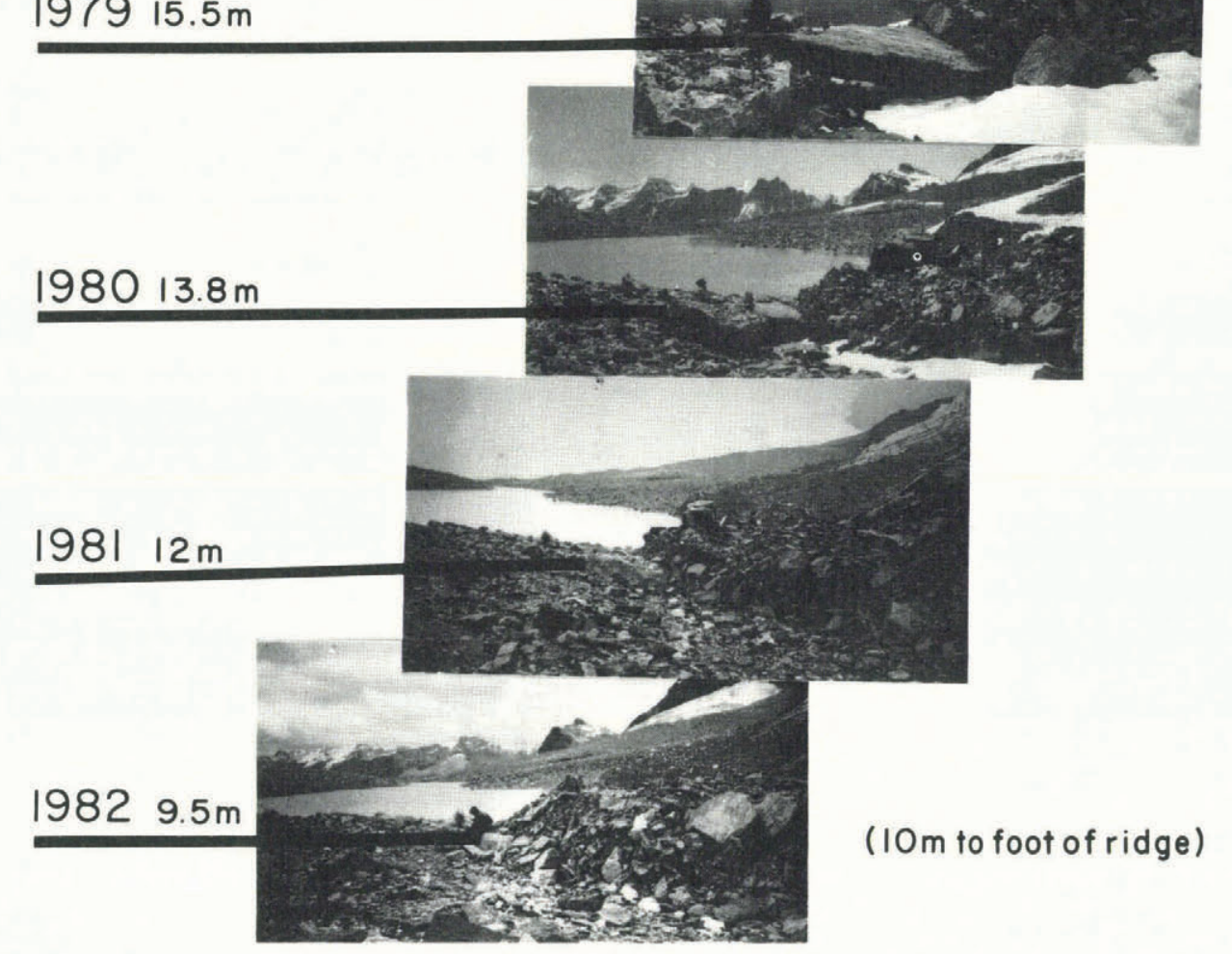

Note: photographs not taken from same site nor of same scale.

\section{RESULTS}

Between 1978 and 1980 , substantial re-advance occurred at site 7 , suggesting support for the qualitative observation of some re-advance along the whole length of moraine $A$ and $B$. Although advance at site $A$ was more marked in 1978-79 (4.57 m) than in 1979-80 $(1.97 \mathrm{~m})$ no data are available to indicate that this contrast applies along the full length of the glacier margin.

Measurable re-advance occurred at most sites during 1980-81, averaging less than one metre along moraine $B$ but almost $2.5 \mathrm{~m}$ along moraine $A$ (Table I). The greatest amount of re-advance occurred in the vicinity of Terminal Lake where the ridge at Site 6 advanced $5.31 \mathrm{~m}$. A similar amount of re-advance was measured just north of the lake during 1978-79 when the ridge at site 7 moved $5.7 \mathrm{~m}$. During 1981-82, readvance along moraine $B$ was negligible, averaging only $0.46 \mathrm{~m}$, with the two southernmost sites showing no forward displacement at all. Along moraine A, displacement was less than in 1980-81 but still averaged $1.62 \mathrm{~m}$ with a maximum amount of $3 \mathrm{~m}$ measured at site 7. Average re-advance for moraine $A$ was consistently higher than for moraine $B$ although less than two standard deviations separate the means in both 1980-81 and 1981-82. This in part is due to a number of low values of displacement in moraine $A$. Most of these 
TABLE I. MEASUREMENTS OF RE-ADVANCE OF EMERALD GLACIER AT SITES SHOWN IN FIGURE 2

Site $\begin{gathered}\text { Marker } \\ \text { Location * }\end{gathered} \quad 1978-79 \quad 1979-80 \quad 1980-81 \quad 1982-82$

\begin{tabular}{|c|c|c|c|c|c|c|}
\hline Moraine B & $\begin{array}{l}1 \\
2 \\
3 \\
4 \\
\\
5\end{array}$ & $\begin{array}{l}B \\
R \\
R_{1} \\
R_{2} \\
B \\
R \\
R\end{array}$ & $\begin{array}{l}- \\
\overline{-} \\
\overline{-} \\
\overline{-} \\
-\end{array}$ & $\begin{array}{l}- \\
- \\
- \\
- \\
-\end{array}$ & $\begin{array}{l}0.06 \\
0.64 \\
0.50 \\
1.00 \\
0.58 \\
1.60 \\
2.58\end{array}$ & $\begin{array}{r}0 \\
0.36 \\
0 \\
0.10 \\
0.41 \\
0.26 \\
2.07\end{array}$ \\
\hline Moraine A & $\begin{array}{r}8 \\
9 \\
10 \\
11 \\
12 \\
13 \\
14 \\
16\end{array}$ & $\begin{array}{c}F \\
R \\
B \\
R \\
F \\
F \\
F \\
R \\
B \\
R / B \\
R_{1} \\
R_{2} \\
B \\
R \\
R \\
R \\
B \\
R \\
R \\
B \\
R_{1} \\
R_{2} \\
R_{3}\end{array}$ & $\begin{array}{r}- \\
3.50 \\
5.70 \\
4.50 \\
- \\
- \\
- \\
- \\
- \\
- \\
- \\
- \\
- \\
- \\
- \\
- \\
- \\
- \\
- \\
-\end{array}$ & $\begin{array}{r}- \\
1.70 \\
2.50 \\
1.70 \\
- \\
- \\
- \\
- \\
- \\
- \\
- \\
- \\
- \\
- \\
- \\
- \\
- \\
-\end{array}$ & $\begin{array}{l}4.91 \\
5.31 \\
1.80 \\
2.80 \\
2.80 \\
1.76 \\
2.21 \\
2.07 \\
3.27 \\
2.30 \\
1.98 \\
0.47 \\
2.84 \\
3.30 \\
2.02 \\
2.51 \\
2.27 \\
0.54 \\
2.06 \\
2.18 \\
2.27\end{array}$ & $\begin{array}{l}1.20 \\
0.89 \\
2.50 \\
1.61 \\
3.00 \\
1.10 \\
1.73 \\
1.66 \\
0.06 \\
1.76 \\
1.56 \\
1.45 \\
1.49 \\
2.55 \\
1.60 \\
1.84 \\
1.60 \\
0.69 \\
1.31 \\
1.57 \\
2.94\end{array}$ \\
\hline $\begin{array}{l}\text { Moraine B } \\
\text { Standard } \\
\text { Moraine A } \\
\text { Standard }\end{array}$ & $\begin{array}{l}\text { verage } \\
\text { viation } \\
\text { verage } \\
\text { viation }\end{array}$ & $\begin{array}{l}\text { re-advance } \\
\text { re-advance }\end{array}$ & $\begin{array}{r}- \\
4.57\end{array}$ & $\begin{array}{r}- \\
1.97\end{array}$ & $\begin{array}{l}0.99 \\
0.846 \\
2.46 \\
1.127\end{array}$ & $\begin{array}{l}0.46 \\
0.730 \\
1.62 \\
0.699\end{array}$ \\
\hline
\end{tabular}

$*^{\mathrm{R}}=$ Ridge crest.

$B=$ Boulder embedded in, or ahead of, distal slope

$F=$ Ridge foot.

Subscripts refer to different locations on same feature.

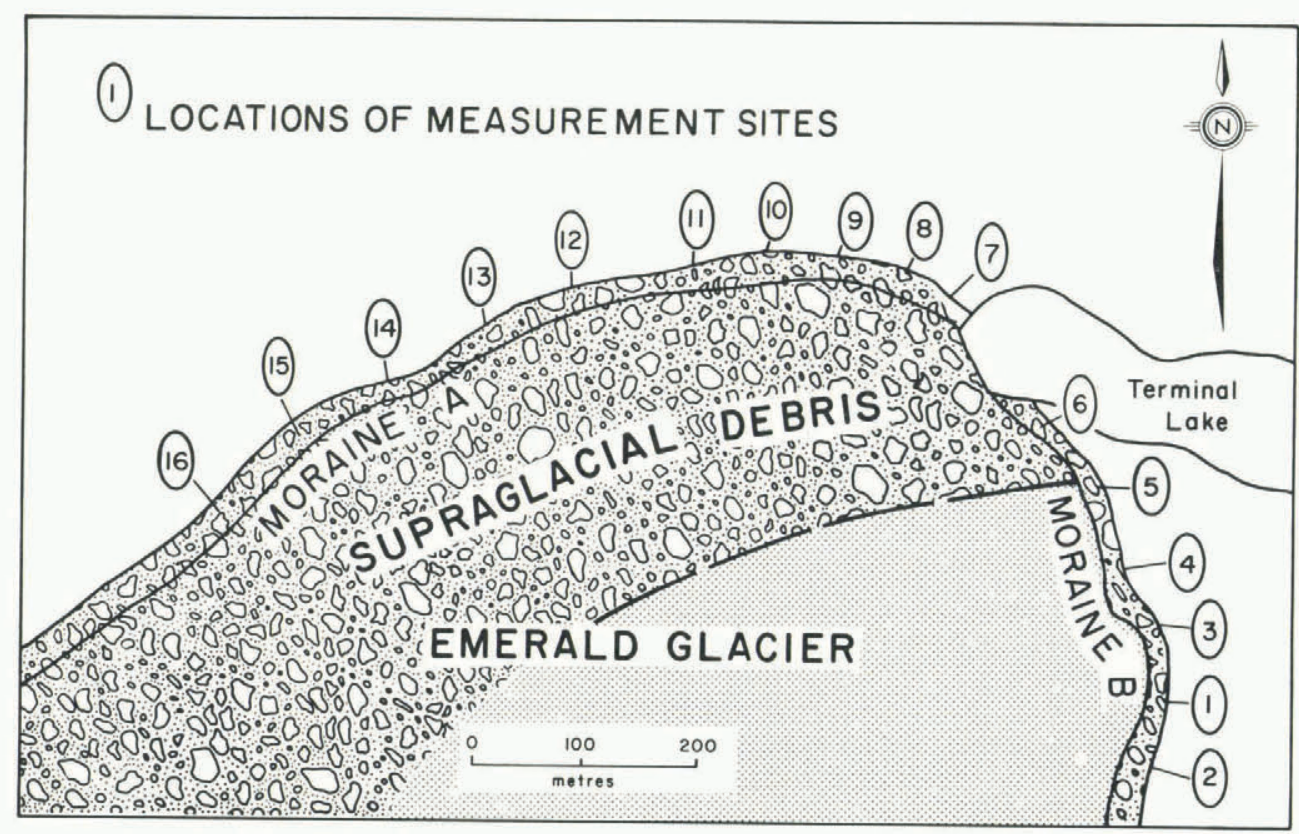

Fig. 2. The approximate location of fixed markers around the terminus of Emerald Glacier. 
low values were obtained from boulders emplaced in the distal slope of the moraine. The boulders are probably partly lodged and in the case of those at sites 12 and 16, moved far less than the ridge measured above them. The differences between ridge crest and boulder displacements represent a general increase in the angle of distal slopes along moraine A and a substantial increase in the height of the moraine ridge. Since 1978 the height of the ridge has approximately doubled in the vicinity of sites 6 and 7 .

\section{DISCUSSION}

In the case of Emerald Glacier it is clear that re-advance is accentuated by the existence of supraglacial debris cover proximal to the push moraine. This may be explained using the two models of push moraines proposed earlier (Rogerson and Batterson, 1982), where thick supraglacial debris cover decreases ice surface melt and allows proximal ice to remain in contact with the moraine ridge throughout the summer. In contrast, the ice margin proximal to moraine $B$ recedes from the moraine during the summer, and during the winter must advance up to $15 \mathrm{~m}$ to the moraine before re-advance displaces any of the markers. Thus, a single glacier may display characteristics of synchronous advance and retreat along the same terminus where there is some alternation between bare ice and supraglacial debris. Where medial moraines meet sections of a glacier terminus, the terminus frequently displays an arcuate bulge or lobe, as noted for Berendon Glacier, British Columbia (Eyles and Rogerson, 1977) and various Icelandic glaciers (Eyles, 1979). The lobe represents a rate of recession which is lower than that for clean ice. Stagnation or disintegration topography is commonly left in zones of high supraglacial debris when the ice margin recedes so far as to abandon the area of low recession rates (Eyles, 1979). Thus, heavily debris-covered glacier termini are often loosely referred to as "dead" or "stagnant" when they may, as in the case of Emerald Glacier, be zones of more vigorous and sustained readvance than adjacent clean ice margins.

Measurements made on the terminus of a rock glacier $2 \mathrm{~km}$ to the north-west indicate no forward displacement of blocks along the terminus since 1978 , despite the presence of soils which appear to have been recently disturbed by re-advance (Fig. 3).

Re-advance of any ice margin may represent recent climatic deterioration reflected in positive glacier mass balances. Mass-balance measurements at Peyto Glacier, less than $20 \mathrm{~km}$ to the north of Emerald Glacier indicated a slight positive mass balance for five of the year years between 1965 and 1974 (Young and Stanley, [C ${ }^{1977]}$ ) although in recent years it has

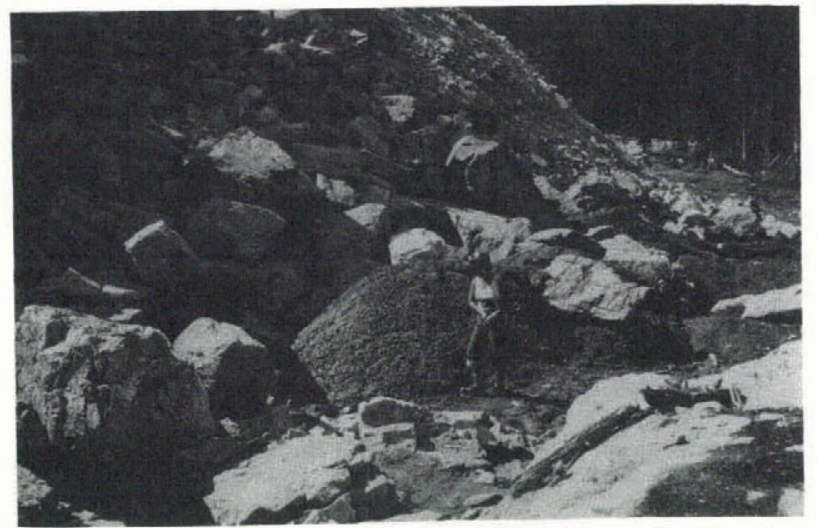

Fig. 3. Blocks and disturbed soils along the front of a rock-glacierized talus slope, $2 \mathrm{~km}$ north-west of the terminus of Emerald Glacier. been negative (personal communication from $\mathrm{J}$. Power in 1982). No mass-balance measurements have been made on Emerald Glacier which has probably, like President Glacier to the north-west (Bray, 1964) and Yoho

Glacier to the north (Bray and Stuik, 1963) retreated for most of the twentieth century from its neoglacial maximum. The current re-advance may merely represent the minor fluctuation of a glacier which has shrunk close to its equilibrium size with respect to present climate. It is however important to monitor this and other small glaciers which have a rapid throughflow of mass and which are likely to respond early to climatic change. If re-advance persists during the present decade, it is likely to be a result of climatic deterioration. Whatever the control, recession should be least, and re-advance greatest, along debriscovered rather than clean ice margins, which suggests that such margins should be singled out for observations of re-advance in any glacierized area.

\section{ACKNOWLEDGEMENTS}

This work was accomplished with the financial support of NSERC operating grants and the permission and co-operation of the Western Region, Parks Canada and the Yoho National Park personnel. Field assistance by Roger Jackson (1978), Martin Batterson and Richard Kodybka (1979), Helène Trudel (1980), and Hazen Russell (1982) is gratefully acknowledged. Drafting and photographic printing were accomplished by staff of the Department of Earth Sciences, Memorial University.

\section{REFERENCES}

Bray, J.R. 1964. Chronology of a small glacier in eastern British Columbia, Canada. Science, Vol. 144, No. 3616, p. 287-88.

Bray, J.R., and Struik, G.J. 1963. Forest growth and glacial chronology in eastern British Columbia and their relation to recent climatic trends. Canadian Journal of Botany, Vol. 41, No. 8, p. 1245-71.

Eyles, N. 1979. Facies of supraglacial sedimentation on Icelandic and Alpine temperate glaciers. Canadian Journal of Earth Sciences, Vol. 16, No. 7, p. 134161.

Eyles, N., and Rogerson, R.J. 1977. Artificially induced thermokarst in active glacier ice: an example from north-west British Columbia, Canada. Journal of Glaciology, Vol. 18, No. 80, p. 437-44.

Gardner, J. [ $\left.{ }^{C} 1972.\right]$ Recent glacial activity and some associated landforms in the Canadian Rocky Mountains. (In Slaymaker, H.0., and McPherson, N.J., ed. Mountain geomorphology: geomorphological processes in the Canadian Ltd., p. 55-62. (B.C. Geographical Series, No. 14.)) Henoch, W.E.S. 1971. Estimate of glaciers [sic] sea lar (1948-1966) volumetric change and its contribution to the discharge in the upper North Saskatchewan River basin. Joumal of Hydrology (Amsterdam), Vol. 12 , No. 2, p. 145-60.

Heusser, C.J. 1956. Postglacial environments in the Canadian Rocky Mountains. Ecological Monographs, 26, p. 263-302.

Ommanney, C.S.L. Unpublished. Canadian glacier variations and mass balance changes. [Quadrennial report to the Permanent Service on the Fluctuation of Glaciers, Federation of Astronomical and Geophysical Services, Canada, 1977.]

porter, S.C., and Denton, G.H. 1967. Chronology of neoglaciation in the North American cordillera. American Journal of Science, Vol. 265, No. 3, p. $177-210$.

Ricker, K.F. 1979. "Snowcap Icefield" and Lake, Garibaldi Park. Ice, No. 59, p. 4-5. 
Ricker, K.E. 1980. Earth science features and glacier regimen of the Clendenning and Elaho Ranges, Coast Mtns, British Columbia. Canadian Alpine Journal, Vol. 63, p. 57-65.

Ricker, K.E. 1981. Corrigenda: Earth science features and glacier regimen of the Clendenning and Elaho Ranges, Coast Mtns, British Columbia. Canadian Alpine Journal, Vol. 64, p. 59-60.

Rogerson, R.J., and Batterson, M.J. 1982. Contemporary push-moraine formation in the Yoho valley, B.C. (In Davidson-Arnott, R., and others, ed. Research in glacial, glacio-fluvial, and glacio-lacustrine systems: proceedings of the 6th Guelph symposium on geomorphology, 1980. Edited by R. Davidson-Arnott, W. Nickling, B.D. Fahey. Norwich, Geo Books in association with Geomorphology Symposium, University of Guelph, p. 71-90. (Dept. of Geography, University of Guelph. Geographical Publication No. 6.))

Tupper, W.A., and Ricker, K.E. 1982. Wedgemount Lake and Glacier studies, northern Garibaldi Park: 1981 progress report. Canadian Alpine Journal, Vol. 65, p. 51-52.

Young, G.J., and Stanley, A.D. [ $\left.{ }^{C} 1977.\right]$ Canadian glaciers in the International Hydrological Decade program, 1965-1974. No. 4, Peyto Glacier, Alberta summary of measurements. Ottawa, Fisheries and Environment Canada. Inland Waters Di rectorate. Inland Waters Branch. (Scientific Series, No. 71.) 